\title{
Survey of Missouri Pesticide Applicator Practices, Knowledge, and Perceptions
}

\author{
Mandy D. Bish and Kevin W. Bradley*
}

The introduction of soybean and cotton traits with resistance to synthetic auxin herbicides has led to an increase in concern over the off-target movement of dicamba and 2,4-D. A direct-mail survey was sent to Missouri pesticide applicators in January of 2016 to understand current herbicide application practices and applicator knowledge and awareness of the new synthetic auxin technologies. Completed surveys were returned by 2,335 applicators, representing approximately $11 \%$ of the state's registered pesticide applicators. Survey data reported herein provides information regarding current pesticide applicator knowledge and practices and highlights areas that need more emphasis during applicator training. Overall, survey respondents were familiar with physical drift and methods to minimize that risk. However respondents were less familiar with volatility and temperature inversions, which can each influence off-target herbicide movement. Of the 427 commercial applicators and 1,535 noncommercial applicators who answered questions regarding volatility, $81 \%$ and $74 \%$ respectively, recognized that high temperatures can contribute to a herbicide's ability to volatilize. However, only $48 \%$ and $39 \%$ understood that a herbicide's vapor pressure influences volatility. Answers from the survey indicate further education is needed on the synthetic auxin technologies, such as what herbicides can be used with each technology, proper methods for inspecting and cleaning spray equipment, and the importance of reading herbicide labels. When asked whether applicators were aware of the new 2,4-D-resistant and dicamba-resistant traits, 76\% of 443 commercial applicators and only $40 \%$ of 1,713 noncommercial applicators selected "yes." Additionally, survey results suggests that current methods aimed to facilitate communication among producers and applicators, such as FieldWatch and Flag the Technology, may not be successfully adopted, at least in Missouri. Findings from this survey can be utilized to enhance training of pesticide applicators in preparation for the synthetic auxin herbicide technologies.

Nomenclature: dicamba; 2,4-D; cotton, Gossypium hirsutum L.; soybean, Glycine max (L.) Merr. Key words: Synthetic auxin herbicide, herbicide label, nozzles, drift-control agents, herbicideresistance traits, herbicide injury, spray tank, contamination, physical drift, volatility, wind speeds, temperature inversion, FieldWatch, Flag the Technology, specialty crops.

\begin{abstract}
La introducción de soja y algodón con resistencia a herbicidas auxinas sintéticas ha generado preocupación por el movimiento accidental de dicamba y 2,4-D a lugares no deseados. En Enero de 2016 se envió una encuesta vía correo directo a aplicadores de plaguicidas con licencia de Missouri para entender las prácticas de aplicación de herbicidas actuales y el conocimiento de los aplicadores acerca de las nuevas tecnologías de auxinas sintéticas. Se recibieron 2,335 encuestas completadas por aplicadores, lo que representó $11 \%$ del registro de aplicadores de plaguicidas del estado. Los datos de la encuesta presentados aquí brindan información acerca del conocimiento y prácticas actuales de los aplicadores de plaguicidas y resaltan las áreas que necesitan mayor énfasis para la capacitación de los aplicadores. En general, los encuestados estaban familiarizados con la volatilidad y las inversiones de temperatura, las cuales pueden influenciar el movimiento accidental del herbicida a zonas no deseadas. De los 427 aplicadores comerciales y los 1,535 aplicadores no comerciales que contestaron las preguntas relacionadas a volatilidad, $81 \%$ y $74 \%$ respectivamente, reconocieron que las altas temperaturas pueden contribuir a la habilidad del herbicida de volatilizarse. Sin embargo, solamente $48 \%$ y $39 \%$ entendía que la presión de vapor del herbicida influencia la volatilidad. Las respuestas en la encuesta indican que se necesita más educación acerca de las tecnologías con auxinas sintéticas, como cuáles herbicidas pueden ser usados con cada tecnología, métodos adecuados para inspeccionar y limpiar los equipos de aspersión, y la importancia de leer la etiqueta del herbicida. Cuando se preguntó si los aplicadores estaban al tanto de los nuevos cultivos con resistencia a 2,4-D y dicamba, 76\% de 443 aplicadores comerciales y solamente $40 \%$ de 1,713 aplicadores no comerciales seleccionaron "sí". Adicionalmente, los resultados de la encuesta sugieren que los métodos actuales dirigidos a facilitar la comunicación entre
\end{abstract}

\footnotetext{
DOI: $10.1017 /$ wet.2016.27

* First and second authors: Senior Research Specialist and Associate Professor, Division of Plant Sciences, University of Missouri, Columbia, MO 65211. Corresponding author's E-mail: bishm@missouri.edu.
} 
productores y aplicadores, tales como FieldWatch y la tecnología de Banderas, podrían no ser adoptadas exitosamente, al menos en Missouri. Los descubrimientos de esta encuesta pueden ser utilizados para mejorar la capacitación de aplicadores de plaguicidas en preparación para el uso de las tecnologías de herbicidas auxinas sintéticas.

Concerns over off-target movement of agricultural chemicals, such as herbicides, date back to the first uses of chemicals to enhance agriculture production. As early as 1927, regulations on agricultural chemicals were established in the United States due to the drift or movement of chemicals to nontarget vegetation following application (Akesson and Yates 1964). Synthetic auxin herbicides such as 2,4-D and dicamba are a class of herbicides that have traditionally provided effective control of a wide range of broadleaf weed species; however, they have also historically been associated with having a high risk of injury to nontarget plants. When these herbicides come in contact with sensitive broadleaf crop or ornamental plants such as cotton (Gossypium hirsutum L.), wine grapes (Vitis vinifera L.), or soybean, they can cause severe injury including leaf cupping, stem and leaf epinasty, cracked and swollen stems, and chlorosis and necrosis of tissues (Al-Khatib et al. 1992; Al-Khatib et al. 1993; Al-Khatib and Peterson 1999; Everitt and Keeling 2009; Solomon and Bradley 2014).

Cotton and soybean with dicamba resistance traits are now commercially available in the United States (USDA-APHIS 2015b; USDA-APHIS 2015c; Inman et al. 2016). The 2,4-D-resistant cotton and soybean traits have been deregulated by the federal government and are anticipated to be available in 2017 (USDA-APHIS 2015a; USDA-APHIS 2014). Few cases of dicamba- or 2,4-D-resistant weeds have been documented since the chemicals were introduced to the market in the last 70 years (Heap 2016), and the introduction of each type of resistance into cotton and soybean can provide additional control options for the most challenging weeds of each production system, such as waterhemp and palmer amaranth (Legleiter and Bradley 2008; Norsworthy et al. 2008).

Proper decision-making by herbicide applicators will be more essential than ever to minimize the risk of these herbicides moving away from the target and onto nontarget plants (Akesson and Yates 1964; Maybank et al. 1978; Soltani et al. 2016; Steckel et al. 2010). Many factors that can contribute to herbicides moving away from target plants and onto nontarget plants, such as physical drift of herbicide droplets and contamination of improperly cleaned spray tanks, can be managed by the applicator (Vangessel and Johnson 2005).

With the important role that herbicide applicators will have in minimizing the off-target movement of synthetic auxin herbicides, an understanding of their current practices, knowledge, and perceptions would be valuable to aid in the improvement of current education and training modules for pesticide applicators. Surveys have been shown to be useful tools in assessing awareness and perceptions (Godar and Stahlman 2015; Norsworthy et al. 2013; Regnier et al. 2016; Shaw et al. 2009; Sinzogan 2004.) The specific objective of this research was to understand the current application practices of Missouri herbicide applicators as well as their knowledge and perception of the synthetic auxin herbicides and factors that contribute to off-target herbicide movement.

\section{Materials and Methods}

A direct-mail survey was developed to investigate the knowledge, skills, and practices of certified Missouri pesticide applicators in January of 2016. A condensed sample of the survey, similar to surveys used by Godar and Stahlmam (2015), is shown in Table 1. Surveys and postage-paid, self-addressed return envelopes were mailed to the 1,387 commercial pesticide applicators certified by the Missouri Department of Agriculture. From the list of 20,880 noncommercial pesticide applicators certified by the Missouri Department of Agriculture, 10,400 applicators were selected. To ensure that surveys were mailed to each county within Missouri, a ratio was developed using the 2012 National Agriculture Census Data on land in row crop production per county, such that counties with the most land in row crop production had the most noncommercial applicators selected for the survey (USDA NASS 2012). Noncommercial pesticide applicators within each county were selected using a random number generator (www.random.org).

The survey comprised three sections (Table 1). Questions in the first section focused on demographic information. Data such as occupation, 
Table 1. Condensed version of survey questionnaire mailed to pesticide applicators. ${ }^{a}$

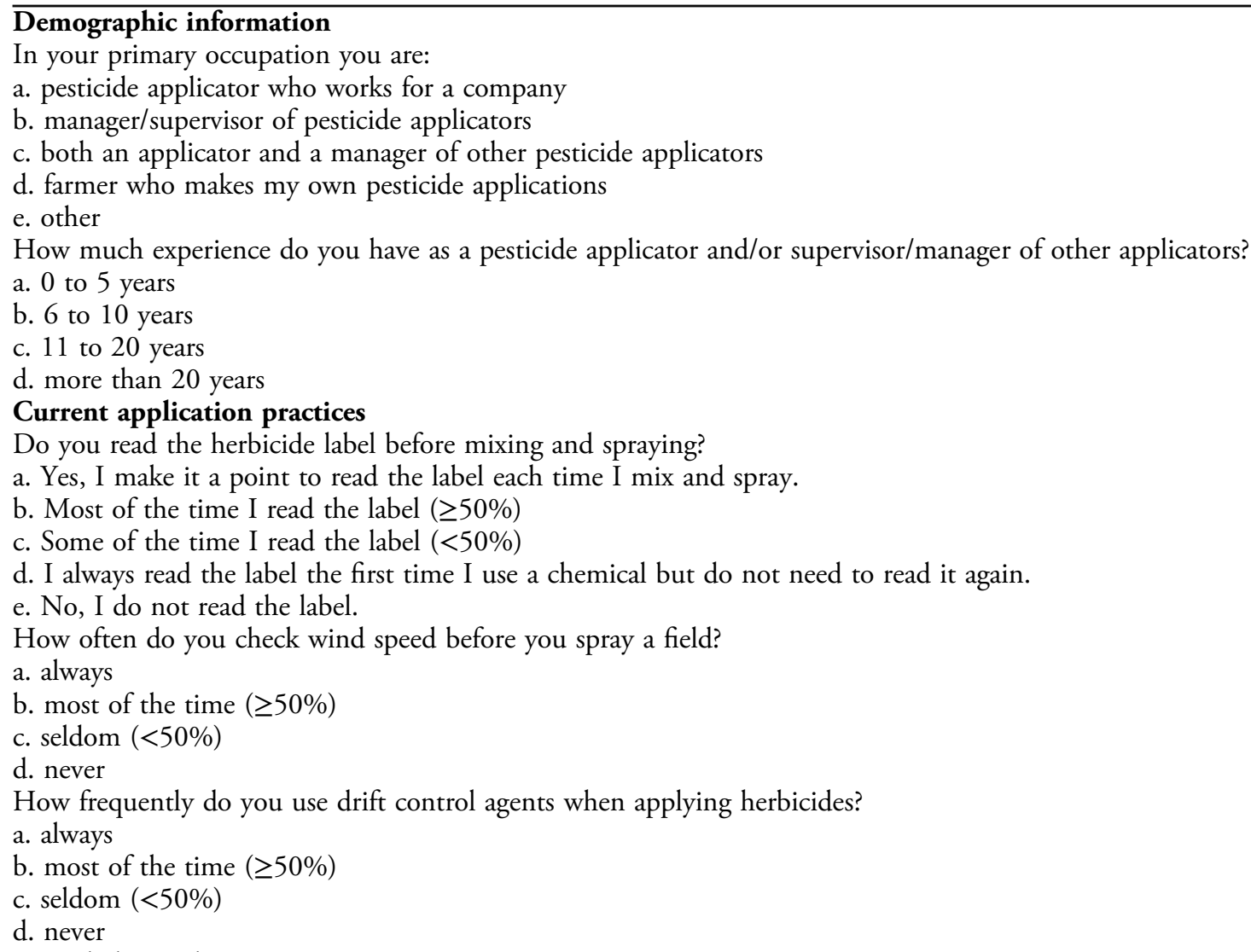

\section{Knowledge and Perception}

Are you aware of the new Enlist and RR2Xtend traits that are expected to be available in cotton and soybean during the 2016 season? a. Yes

b. No

RR2Xtend cotton and soybean varieties will tolerate applications of dicamba and 2,4-D

a. True

b. False

\footnotetext{
a The complete questionnaire was 41 questions in length and mailed to all 1,387 Missouri commercial pesticide applicators and 10,440 of the 20,880 private pesticide applicators.
}

number of acres sprayed, and experience with herbicide application were collected. The second section of the survey was designed to collect data on common current herbicide application practices. Applicators were asked questions about application routines, such as the practice of reading herbicide labels, methods for checking wind speed, and procedures for tank cleanout following a herbicide application. The third section of the survey focused on knowledge and perceptions regarding herbicide applications. Respondents were asked questions pertaining to the new synthetic auxin herbicideresistant traits, common conditions associated with off-target herbicide movement, and fault following misapplication of herbicides.
Survey data were entered into a spreadsheet format for analysis (Shaw et al. 2009). For the subset of questions where applicators were asked to "select all that apply", data were sorted and analyzed in crosstabulation tables using PROC SURVEYFREQ in SAS $^{\circledR} 9.4$ (SAS Inst., Cary, NC). Not every respondent answered each question; the total number of respondents for a particular survey question is included for each question presented in the results and discussion.

\section{Results and Discussion}

A total of 2,335 surveys were returned, representing approximately $11 \%$ of registered pesticide applicators in Missouri. Over 19\% of respondents 
indicated that they represented pesticide applicators for companies, managers of applicators, or both $(150,144$, and 163 respondents, respectively). These three categories of respondents were grouped together as commercial applicators and presented separately from the noncommercial applicators who identified themselves as farmers $(1,633)$ or other (245). Of all respondents, $72 \%$ of commercial applicators and $75 \%$ of noncommercial applicators had more than 10 years of experience with pesticide applications. Only $15 \%$ and $13 \%$ of the commercial and the noncommercial respondents, respectively, had zero to five years of experience.

\section{Current Herbicide Application Practices}

Reading the Label. When asked how frequently they read herbicide labels prior to mixing and spraying, $49 \%$ and $61 \%$ of commercial and noncommercial applicators, respectively, indicated that they read herbicide labels more than $50 \%$ of the time (Table 2). Of this group of respondents, $52 \%$ of commercial and $47 \%$ of noncommercial applicators claimed that herbicide labels were clear and straightforward; $45 \%$ and $51 \%$, respectively, stated that labels are mostly clear but leave the applicators with a few questions; and approximately $2 \%$ from each group claimed that labels were unclear (data not shown). Collectively, these data suggest that when applicators take time to read the labels, they find the information mostly clear. However, the results also indicate the need to place more emphasis on taking time to read herbicide labels prior to mixing.
Physical Drift of Herbicides. Survey recipients were asked questions pertaining to practices that impact the physical drift of herbicide droplets wherein herbicide particles are moved away from intended targets and possibly onto nontargeted plants. When asked at what wind speeds they considered it too windy to make an herbicide application, $43 \%$ of commercial and $53 \%$ of noncommercial applicators indicated wind speeds exceeding $16 \mathrm{~km} \mathrm{~h}^{-1}$ (Table 3). This is the same wind speed cutoff that the Environmental Protection Agency recommends for minimizing physical drift (Pfleeger et al. 2006). Many dicamba and 2,4-D herbicide labels indicate that applicators should avoid spraying in wind speeds exceeding $24 \mathrm{~km} \mathrm{~h}^{-1}$, which was the wind speed selected by $38 \%$ of commercial and $20 \%$ of noncommercial applicators (Anonymous 2006; Anonymous 2008; Anonymous 2010; Anonymous 2012; Anonymous 2016). A subset of applicators did not select a wind speed but opted for "Other", and their explanations included, but were not limited to, "depends on what chemical is being used", "depends on what is downwind of the field being sprayed", "never too windy to spray", and "depends on how far behind we are". These results indicate that a high percentage of Missouri applicators are aware of proper wind speeds for herbicide applications. To determine if applicators follow through with their knowledge of wind speeds, survey recipients were asked about the frequency and methods with which they check wind speed prior to spraying a field. Over $95 \%$ of each group indicated that they check wind

Table 2. Missouri pesticide applicators' practices of reading herbicide labels.

\begin{tabular}{llr}
\hline & Frequency of reading the herbicide label ${ }^{\mathrm{a}}$ & \# of respondents $(\%)$ \\
\hline Commercial applicators & Each time before mixing & $118(26)$ \\
& Most of the time $(\geq 50 \%)$ & $102(23)$ \\
& Some of the time $(<50 \%)$ & $170(12)$ \\
& The first time & $138)$ \\
Noncommercial applicators & Do not read the label & $8(1)$ \\
& Total & $451(100)$ \\
& Each time before mixing & $855(46)$ \\
& Most of the time $(\geq 50 \%)$ & $277(15)$ \\
& Some of the time $(<50 \%)$ & $115(6)$ \\
The first time & $594(32)$ \\
& Do not read the label & $21(1)$ \\
& Total & $1,862(100)$ \\
\hline
\end{tabular}

\footnotetext{
a Survey respondents were asked, "Do you read the herbicide label before mixing and spraying?"

b The full-length answer on the survey was, "I always read each label the first time I use a chemical but do not need to read it again."
} 
Table 3. Missouri pesticide applicators' knowledge and practices of checking wind speeds prior to making herbicide applications.

\begin{tabular}{|c|c|c|c|c|}
\hline & $\begin{array}{l}\text { Maximum wind speeds }{ }^{\mathrm{a}} \\
\qquad \mathrm{km} \mathrm{h}^{-1}\end{array}$ & $\begin{array}{c}\text { \# of } \\
\text { respondents }(\%)\end{array}$ & $\begin{array}{c}\text { Frequency of checking wind speed } \\
\text { prior to application }{ }^{b}\end{array}$ & $\begin{array}{c}\text { \# of } \\
\text { respondents }(\%)\end{array}$ \\
\hline \multirow[t]{4}{*}{ Commercial applicators } & Wind $>8 \mathrm{~km} \mathrm{~h}^{-1}$ & $23(5)$ & Always & $324(72)$ \\
\hline & Wind $>24 \mathrm{~km} \mathrm{~h}^{-1}$ & $164(38)$ & Some of the time $(<50 \%)$ & $17(4)$ \\
\hline & Wind $>32 \mathrm{~km} \mathrm{~h}^{-1}$ & $26(6)$ & Never & $3(<1)$ \\
\hline & Other ${ }^{c}$ & $33(8)$ & & \\
\hline \multirow{5}{*}{ Noncommercial applicators } & Wind $>16 \mathrm{~km} \mathrm{~h}^{-1}$ & $914(53)$ & Most of the time $(\geq 50 \%)$ & $384(21)$ \\
\hline & Wind $>24 \mathrm{~km} \mathrm{~h}^{-1}$ & $354(20)$ & Some of the time $(<50 \%)$ & $61(3)$ \\
\hline & Wind $>32 \mathrm{~km} \mathrm{~h}^{-1}$ & $48(3)$ & Never & $22(1)$ \\
\hline & Other $^{c}$ & $75(4)$ & & \\
\hline & Total & $1,736(100)$ & Total & $1,837(100)$ \\
\hline
\end{tabular}

a Survey respondents were asked, "At what point would you consider it too windy to spray herbicides?"

b Survey respondents were asked, "How often do you check wind speed before you spray a field?"

" Explanations for "other" included, but were not limited to, "depends on what chemical is being used", "depends on what is downwind of the field being sprayed", "never too windy to spray", and "depends on how far behind we are".

speeds $\geq 50 \%$ of the time (Table 3 ). For this group of respondents, the primary method(s) for checking wind speed varied (Figure 1). The most common method selected by noncommercial applicators was estimating by looking at surroundings (47\%), followed by looking online at the nearest weather station (27\%). Commercial applicators were most likely to use handheld anemometers (35\%), check the nearest weather station online $(27 \%)$, or use a smartphone app (26\%). These data reveal that most Missouri applicators are aware that wind is an important factor in deciding to make herbicide applications, and are committed to checking the wind speed prior to spraying. However, the methods by which applicators check the wind speed are variable and, for many noncommercial applicators, are likely unreliable.

Excluding wind speeds and spray boom heights, the size of spray droplets may have the next largest impact on whether herbicide particles are likely to drift (Creech et al. 2015). Specific spray nozzle types have been developed to increase herbicide droplet size and maintain herbicide efficacy, and the herbicide labels for the new formulations of 2,4-D and dicamba will require specific spray nozzles (Anonymous 2016). When asked about frequency with which applicators change nozzles, $9 \%$ to $10 \%$ from each group indicated they always change

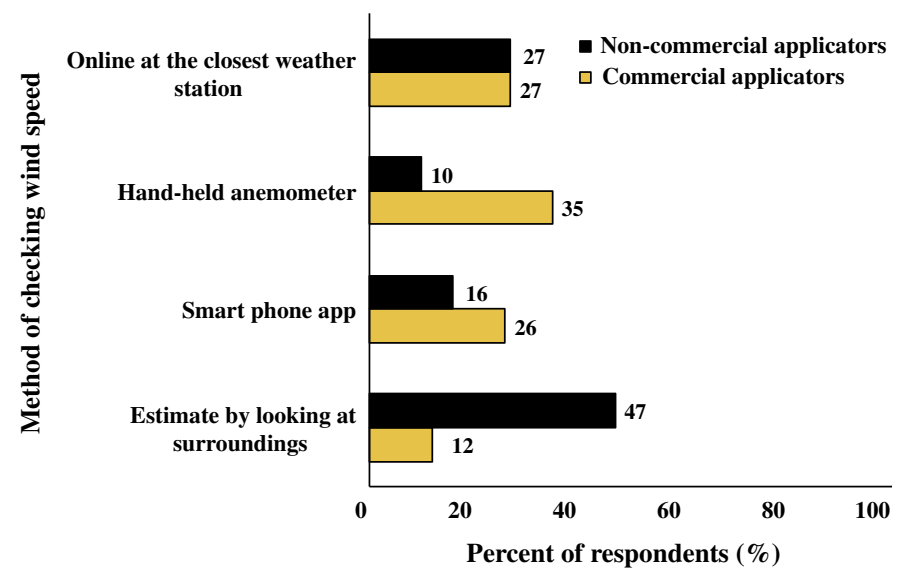

Figure 1. The primary methods Missouri pesticide applicators use for checking wind speed prior to herbicide applications. Only the 433 commercial and 1,754 noncommercial herbicide applicator respondents who indicated in a previous question that they check the wind speed $\geq 50 \%$ of the time prior to making herbicide applications were considered. 
Table 4. Missouri pesticide applicators' implementation of practices to reduce physical drift during herbicide applications.

\begin{tabular}{|c|c|c|c|c|}
\hline & $\begin{array}{l}\text { Frequency of } \\
\text { changing nozzles }\end{array}$ & $\begin{array}{c}\text { \# of } \\
\text { respondents }(\%)\end{array}$ & $\begin{array}{l}\text { Frequency of using drift } \\
\text { control agents }\end{array}$ & $\begin{array}{c}\text { \# of } \\
\text { respondents }(\%)\end{array}$ \\
\hline \multirow[t]{4}{*}{ Commercial applicators } & Always & $45(10)$ & Always & $143(32)$ \\
\hline & Some of the time $(<50 \%)$ & $207(46)$ & Some of the time $(<50 \%)$ & $97(21)$ \\
\hline & Never & $73(16)$ & Never & $24(5)$ \\
\hline & Total & $453(100)$ & Total & $453(100)$ \\
\hline & Some of the time $(<50 \%)$ & $759(42)$ & Some of the time $(<50 \%)$ & $499(28)$ \\
\hline & Never & $551(31)$ & Never & $428(24)$ \\
\hline & Total & $1,801(100)$ & Total & $1,814(100)$ \\
\hline
\end{tabular}

a Survey respondents were asked, "How often do you change nozzles for different types of herbicide products?"

b Survey respondents were asked, "How frequently do you use drift control agents when applying herbicides?"

nozzles, while $62 \%$ of commercial and $73 \%$ of noncommercial applicators reported that they change nozzles $<50 \%$ of the time (Table 4 ).

Drift control agents can also impact the size of droplets by altering the viscosity of the spray solution through reducing the liquid's ability to stretch and separate into small droplets (VanGessel and Johnson 2005). When asked how frequently applicators added drift control agents to the solution, $74 \%$ of commercial and $48 \%$ of noncommercial applicators indicated that they use drift control agents $\geq 50 \%$ of the time (Table 4). Approximately 5\% of commercial applicators and $24 \%$ of noncommercial applicators indicated that they never use drift control agents. These survey results suggest that commercial herbicide applicators are adopting techniques to help mitigate physical drift. However, there seems to be a lack of knowledge or adoption, or both, by noncommercial applicators regarding new technologies that can help mitigate physical herbicide drift.

Spray Tank Inspection and Cleanout Practices. Because the synthetic auxin herbicides are not as water soluble as other herbicides commonly used in the Midwest, such as glyphosate, more emphasis will likely be needed with regards to cleaning and inspecting spray tanks and parts for herbicide accumulation following synthetic auxin herbicide application (Steckel et al. 2010). Applicators were asked a series of questions pertaining to maintenance and cleaning of spray equipment. When asked how many times the applicator rinses the spray tank after spraying one herbicide and prior to mixing a different herbicide, $65 \%$ of the 444 commercial respondents who answered reported that they rinse the tank three times, and 18\% indicated that they clean the tank at least twice (data not shown). Of the 1,728 noncommercial applicators who answered the question, $43 \%$ indicated that they triple rinse, while $33 \%$ responded that they clean the tank at least once. "I do not typically rinse my tank in between herbicide applications" was a possible answer, which $1 \%$ of commercial and $3 \%$ of noncommercial applicators selected; $6 \%$ of commercial and $13 \%$ of noncommercial applicators indicated that they rinsed the tank once between applications. "Other" was selected by $10 \%$ of commercial and $8 \%$ of noncommercial applicators. The most common explanations for "other" were "depends on what crop will be sprayed next" and "depends on what chemical is being used".

Of those who indicated that they rinse the spray tank three times or more, $67 \%$ of commercial and $44 \%$ of noncommercial applicators use specialized tank cleanout products $\geq 50 \%$ of the time (Table 5). Less than $2 \%$ of these respondents indicated "other" with regard to specialized products. Explanations varied, but included "depends on the product that has been sprayed", "use household ammonia", and "if the herbicide label requires". Of respondents who rinse the spray tank fewer than three times between herbicide applications, $56 \%$ of commercial and 35\% of noncommercial applicators use specialized tank cleanout products $\geq 50 \%$ of the time. These results suggest a slower adoption of techniques to mitigate spray tank contamination by noncommercial applicators compared to that of commercial applicators, and are consistent with slower adoption of physical 
Table 5. The frequency with which Missouri pesticide applicators rinse spray tanks and use specialized tank cleanout products after making herbicide applications.

\begin{tabular}{|c|c|c|c|c|c|c|c|c|}
\hline & $\begin{array}{c}\text { Number of } \\
\text { rinses }^{c}\end{array}$ & \multicolumn{7}{|c|}{ Frequency of using specialized tank cleanout products ${ }^{\mathrm{a}, \mathrm{b}}$} \\
\hline Commercial applicators & $<3$ times & $25(23)$ & $36(33)$ & $24(22)$ & $11(10)$ & $13(12)$ & $1(<1)$ & $110(100)$ \\
\hline Noncommercial applicators & 3 times & $180(25)$ & $142(19)$ & $150(20)$ & $170(23)$ & $79(11)$ & $15(2)$ & $736(100)$ \\
\hline
\end{tabular}

\footnotetext{
${ }^{a}$ Survey respondents were asked, "How often do you use specialized tank cleanout products in addition to water during sprayer tank cleanout?"

b Reported data is in the following format: Number of respondents (\% of respondents).

c Survey respondents were asked, "How many times do you rinse your spray tank after spraying a herbicide and prior to mixing a different herbicide?"
}

drift reduction methods by noncommercial applicators compared that of commercial applicators. This could be due to multiple factors, such as the time it takes to clean tanks out properly, the cost of adding drift reduction chemicals, and a lack of understanding of how the chemical properties of synthetic auxin herbicides are different from other commonly used herbicides. It is also likely that noncommercial applicators may plant the same variety of crop in each of their fields and therefore switch between chemicals less frequently than commercial applicators do. Regardless, the results suggest that going forward emphasis will need to be placed on proper cleanout of spray tanks for both applicator groups.

The use of nurse tanks with premixed herbicide solutions that can be shuttled to the applicator can allow the workload to be carried out more efficiently. However, nurse tanks also introduce another component to the system that can lead to herbicides moving off-target if the nurse $\operatorname{tank}(s)$ are not cleaned properly. When asked about the frequency with which applicators used nurse tanks, $60 \%$ of 273 commercial respondents and $82 \%$ of 1,497 noncommercial applicators indicated that they never use nurse tanks (data not shown). Of the remainder, $26 \%$ of commercial and $6 \%$ of noncommercial applicators reported that they use nurse tanks most of the time ( $\geq 50 \%)$. Approximately $1 \%$ within each group selected "other", and explanations included "depends on the chemicals", "hot loads are dedicated for corn only", and "often during PRE applications but never in POST".

Chemical residue buildup and/or damage to sprayer parts are additional sources that can lead to spray tank contamination and/or faulty applications. When asked about the frequency with which sprayer parts are inspected for damage and/or chemical residue buildup, $69 \%$ of commercial and $74 \%$ of noncommercial respondents indicated that they check parts a minimum of once per week (Table 6). A subset of respondents from each group (16\% of commercial and $7 \%$ of noncommercial) opted not to select a frequency but chose "other". Explanations for "other" included, but were not limited to, "depends on the product being used", "when switching between chemicals", "when switching between crops", "anytime the sprayer is flushed", and "depends on the sprayer part". Of respondents who inspect sprayer parts a minimum of once a month, over $90 \%$ indicated that they routinely inspect spray nozzles, and over $80 \%$ of noncommercial and $90 \%$ of commercial applicators check in-line filters routinely (Figure 2). Parts not inspected as frequently included spray tanks, end caps, spray lines, and inductors. However these parts also provide opportunities for herbicide contamination. These current practices with regard to spray tank maintenance and cleanout will likely be a key cause of synthetic auxin herbicides moving off-target. Recent work from Cundiff et al. (2016) has shown that the quality of spray lines and cracks within the spray lines provide opportunities for dicamba to settle out of solution and go unrinsed when cleaning out the spray tank. Going forward, proper education and demonstration on spray tank cleanout and maintenance will continue to be essential. Applicators need to be aware that in previous years spray tank contamination and/ or faulty applications may have gone largely unnoticed 
Table 6. The frequency with which Missouri pesticide applicators inspect sprayer parts. ${ }^{a}$

\begin{tabular}{lcc}
\hline & Commercial applicators & Noncommercial applicators $^{\mathrm{b}}$ \\
\hline Before each use & $167(38)$ & $873(51)$ \\
Approximately once per week & $135(31)$ & $386(23)$ \\
Approximately once to twice per month & $40(9)$ & $99(6)$ \\
Approximately once to twice per season & $26(6)$ & $230(13)$ \\
Other & $69(16)$ & $126(7)$ \\
Total & $437(100)$ & $1,714(100)$ \\
\hline a Survey respondents were asked, "How frequently do you inspect sprayer parts for damage and/or chemical residue \\
build-up?" \\
b Reported data is in the following format: Number of respondents (\% of respondents). \\
c Responses for "other" included, but were not limited to, "depends on the product being used", "when switching \\
between chemicals", "when switching between crops", "anytime the sprayer is flushed", and "depends on the \\
sprayer part".
\end{tabular}

with the majority of the US soybean, cotton, and corn crops being glyphosate resistant. However, with the introduction of multiple new herbicide-resistant soybean and cotton traits, spray tank contamination will be more likely to lead to injury of subsequentlysprayed crops. Additionally, the nature of the herbicides, and specifically, the ability of dicamba to precipitate out of solution, will provide more opportunities for tank contamination to occur.

\section{Applicator Knowledge and Perceptions.}

Understanding applicator knowledge and perceptions of the new synthetic auxin technologies and factors that contribute to off-target movement of the corresponding herbicides should provide further insights into education and training needs. When asked about awareness of the new Enlist ${ }^{\circledR}$ (2,4-D resistant) and Roundup Ready 2 Xtend $^{\circledR}$ (RR2Xtend) (dicamba-resistant) traits in cotton and soybean, $76 \%$ of 443 commercial and $40 \%$ of 713 noncommercial applicator respondents indicated that they were aware of them (data not shown). For those who were aware, a series of three "true or false" questions was asked to determine applicators' levels of knowledge on the traits. Of those respondents, $67 \%$ of the noncommercial and $79 \%$ of the commercial applicators knew that Enlist ${ }^{\circledR}$ varieties tolerate applications of 2,4-D; $59 \%$ of the noncommercial and $73 \%$ of the commercial respondents also knew that not all dicamba formulations will be approved for POST applications in the RR2Xtend crops (Table 7). The question in this set that was answered least correctly was whether RR2Xtend crops can tolerate applications of 2,4-D and dicamba; $51 \%$ of noncommercial and $69 \%$ of commercial applicators correctly indicated that RR2Xtend cannot tolerate 2,4-D. Collectively, these data indicate that approximately $24 \%$ of commercial

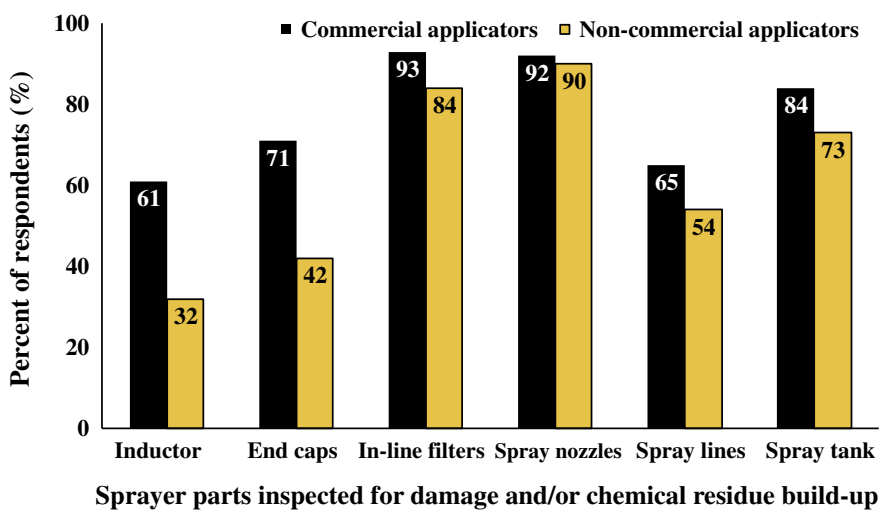

Figure 2. The sprayer parts most commonly inspected by Missouri pesticide applicators. The 342 commercial and 1,358 noncommercial applicators who reported that they inspect sprayer parts a minimum of once to twice a month were asked to select all parts of the sprayer they inspect. Data is graphed as the percentage of respondents who selected each sprayer part. 
Table 7. Missouri pesticide applicators' understanding of new cotton and soybean traits.

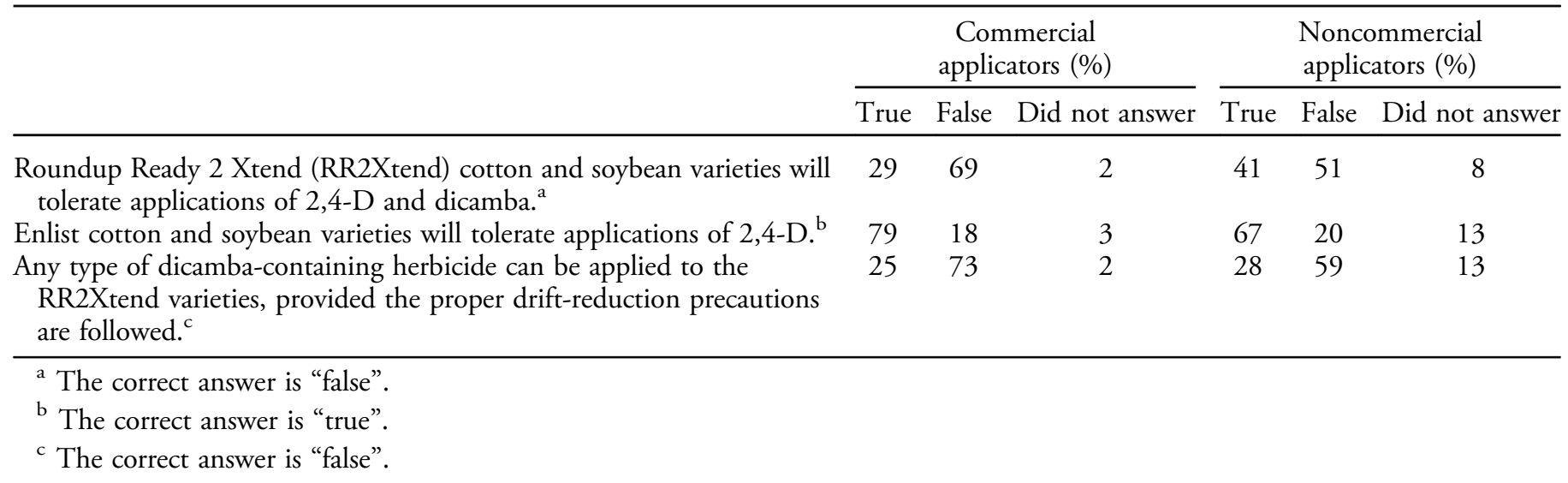

and 60\% noncommercial applicators in Missouri are unaware of the Enlist ${ }^{\circledR}$ and RR2Xtend technologies. Combined with the responses on the true/false questions, these results highlight the need for continued education on the RR2Xtend and Enlist ${ }^{\circledR}$ technologies. Lack of understanding with regard to these technologies may be one factor that has contributed to the nonlabel use of dicamba as a POST treatment in Roundup Ready 2Xtend ${ }^{\circledR}$ cotton during the 2016 growing season (EPA 2016).

When asked knowledge- and perception-based questions regarding the off-target movement of herbicides, $92 \%$ of the 451 commercial applicator respondents and $91 \%$ of the 1,781 non-commercial applicator respondents were aware that fine spray droplets are more likely to drift than "very coarse" or "extremely coarse" droplets (data not shown). The majority of respondents, $97 \%$ of 443 commercial applicators and $91 \%$ of 1,734 noncommercial applicator respondents, were also aware that many herbicide labels require allowing for buffer zones between the application area and sensitive areas (data not shown). To follow up on the question regarding sensitive areas, respondents were given a list of five areas including a body of water, an area that serves as a habitat for endangered species, fallow crop land, a nearby residential area, and a different crop that would be injured by the herbicide being applied, and were asked to select all that might classify as "sensitive areas". Of those who knew that herbicide labels have information on sensitive areas, over $90 \%$ of each group knew that "a body of water" and "a different crop that would be injured by the herbicide" could be classified as sensitive (data not shown). Over $80 \%$ of both groups recognized that areas that are habitats for endangered species and nearby residential areas are classified as sensitive areas. Fallow cropland was the most varied response, as $31 \%$ of commercial applicants and $28 \%$ of noncommercial applicants incorrectly selected that fallow cropland would be classified as a sensitive area.

Facilitating communication among pesticide applicators, cotton and soybean growers, and specialty crop producers in order to identify sensitive areas or label the type of resistance trait in a field is one possible method to help reduce the amount of herbicides, including synthetic auxin herbicides, that may end up on non-target plants. FieldWatch is a web-based utility aimed to facilitate communication; $57 \%$ of commercial and $16 \%$ of noncommercial applicators indicated that they were aware of FieldWatch (Figure 3) (Maynard et al. 2012). Of those who had heard of FieldWatch, 18\% of commercial and $27 \%$ of noncommercial applicators responded that they intend to "always" check FieldWatch before making herbicide applications in the future, while $46 \%$ of commercial and $41 \%$ of noncommercial responded that they intend to check FieldWatch $<50 \%$ of the time (Table 8). Flag the Technology is another communication tool that promotes the placement of a physical, color-coded flag at the entrance of the field. The color of each flag represents a specific herbicide-resistance trait (Scott et al. 2011). Less than half of all respondents indicated that they were aware of Flag the Technology (Figure 4) (Scott et al. 2011). Of those who were aware of it, $8 \%$ of commercial and $12 \%$ of noncommercial applicators indicated that they plan to 'always' use the technology, while $57 \%$ of commercial and $45 \%$ of noncommercial indicated 


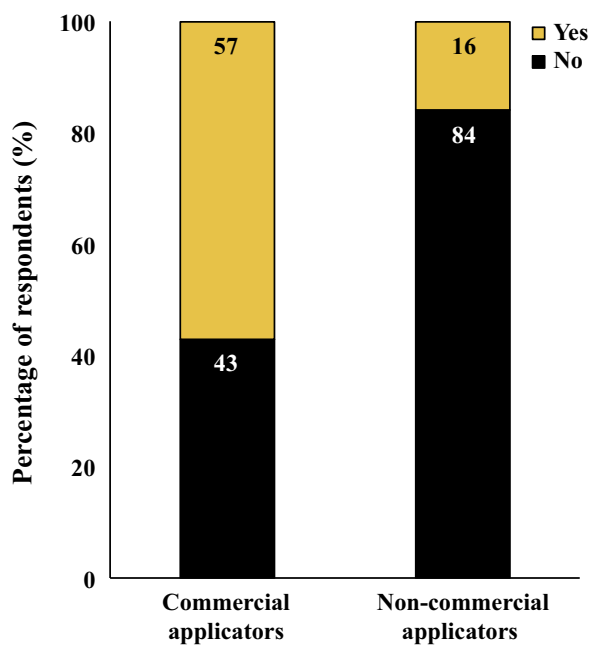

Figure 3. Missouri pesticide applicators' awareness of FieldWatch (DriftWatch), a tool aimed to facilitate communication between applicators and specialty crop producers. Survey respondents were asked whether they were aware of the web-based sensitive crop registration service called FieldWatch or DriftWatch.

that they plan to use the technology less than $50 \%$ of the time (Table 8). These results suggest that, although efforts are being made to facilitate communication, applicators may be slow adopters of the new communication tools until they fully recognize the value of each.

To understand applicator mindset regarding what factors are most likely to contribute to off-target herbicide movement, respondents were given three

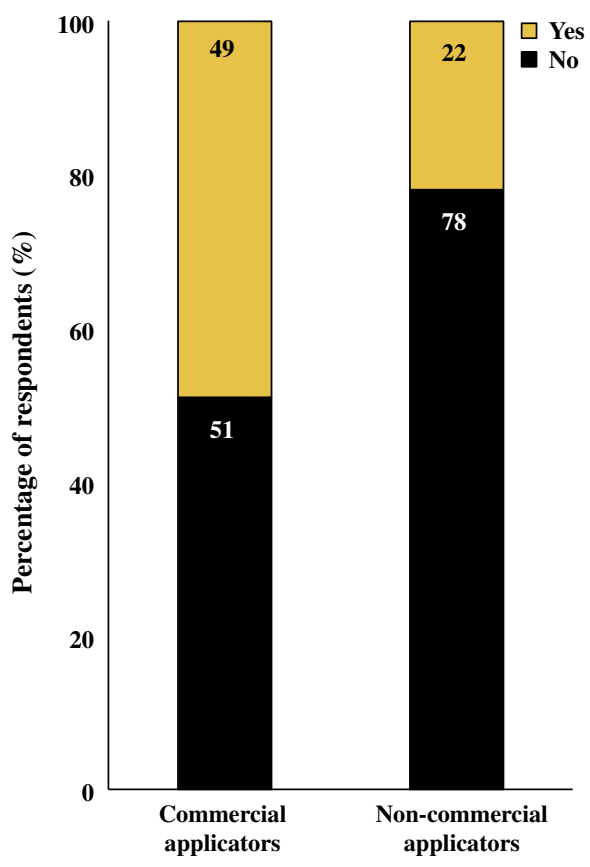

Figure 4. Missouri pesticide applicators' awareness of Flag the Technology, a tool aimed to facilitate communication between applicators regarding what herbicide-resistance traits are present in the field. Survey respondents were asked whether they were aware of Flag the Technology.

factors, drift, volatility, and tank contamination, and asked to rank them in order from least likely to lead to off-target movement of 2,4-D and dicamba to most likely to lead to off-target movement, with

Table 8. Missouri pesticide applicators' willingness to implement FieldWatch and/or Flag the Technology.

\begin{tabular}{|c|c|c|c|c|}
\hline & $\begin{array}{l}\text { Anticipated frequency of } \\
\text { using FieldWatch }\end{array}$ & $\begin{array}{c}\text { \# of } \\
\text { respondents (\%) }\end{array}$ & $\begin{array}{l}\text { Anticipated frequency of } \\
\text { using Flag the Technology }\end{array}$ & $\begin{array}{c}\# \text { of } \\
\text { respondents }(\%)\end{array}$ \\
\hline \multirow[t]{4}{*}{ Commercial applicators } & Always & $45(18)$ & Always & $18(8)$ \\
\hline & Some of the time $(<50 \%)$ & $91(36)$ & Some of the time $(<50 \%)$ & $106(48)$ \\
\hline & Never & $26(10)$ & Never & $20(9)$ \\
\hline & Did not answer & $1(<1)$ & Did not answer & $11(5)$ \\
\hline \multirow{5}{*}{ Noncommercial applicators } & Most of the time $(\geq 50 \%)$ & $89(30)$ & Most of the time $(\geq 50 \%)$ & $153(38)$ \\
\hline & Some of the time $(<50 \%)$ & $82(28)$ & Some of the time $(<50 \%)$ & $152(37)$ \\
\hline & Never & $39(13)$ & Never & $33(8)$ \\
\hline & Did not answer & $6(2)$ & Did not answer & $21(5)$ \\
\hline & Total & $295(100)$ & Total & $408(100)$ \\
\hline
\end{tabular}

${ }^{\text {a }}$ Survey respondents were asked, "How often do you intend to check the DriftWatch or FieldWatch sensitive crop registry before making herbicide applications in the future?"

${ }^{\mathrm{b}}$ Data is presented only for those applicators who indicated in previous survey questions that they were aware of FieldWatch and/or Flag the Technology.

"Survey respondents were asked, "How much do you expect you will see Flag the Technology utilized in your fields in the near future?" 


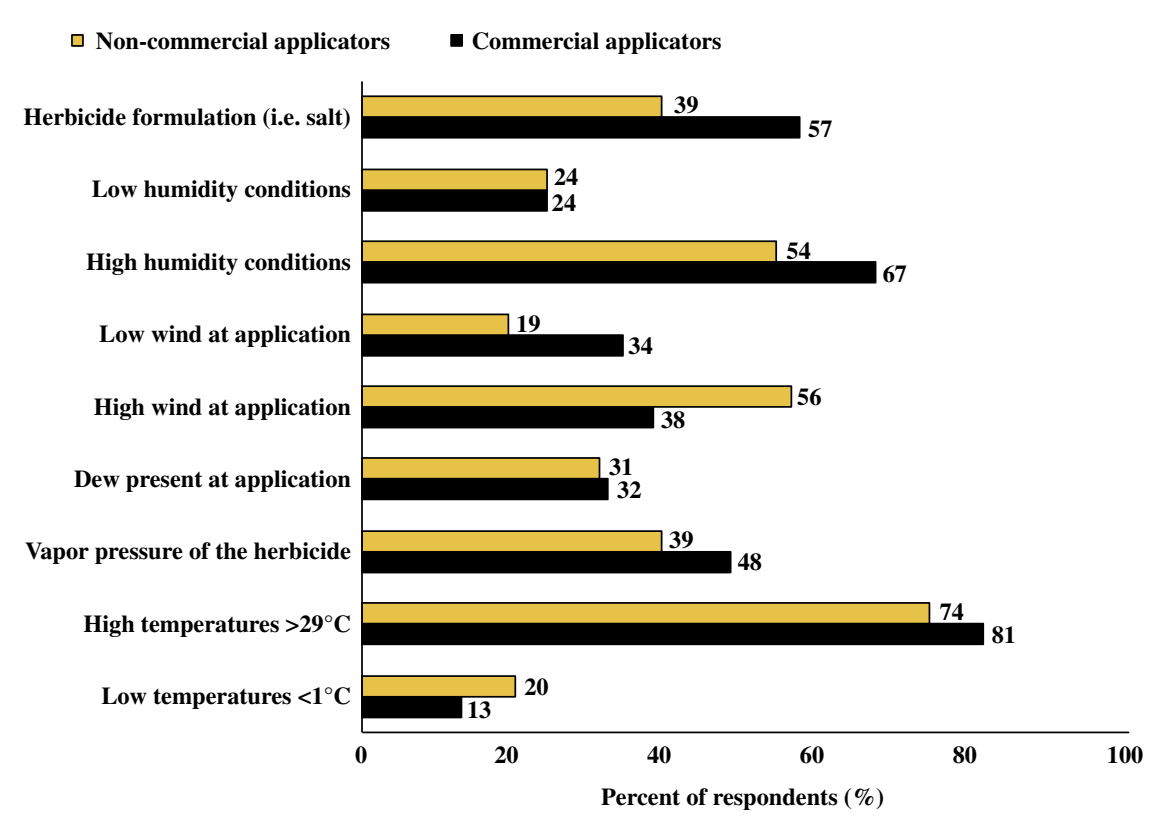

Figure 5. Factors that contribute to volatility. Missouri pesticide applicators were asked whether each of the listed factors (y-axis) was likely to influence the volatilization potential of an herbicide. Gold bars represent the percentage of noncommercial applicators $(n=1,535)$ who indicated that a given factor could influence volatility. Black bars represent the percentage of commercial applicators $(n=427)$ who indicated that a given factor could influence volatility.

1 being least and 3 being most likely. Both groups (457 commercial and 1,878 noncommercial applicators responding) ranked drift as the most likely factor of the three to contribute to off-target movement, followed by volatility and then tank contamination (data not shown).

Environmental factors can influence the volatility of herbicides, allowing herbicide particles to evaporate from their landing surfaces and move back into the air where they can be moved by wind. To assess pesticide applicator understanding of volatility, respondents were given a list of nine factors: low temperatures $(<1 \mathrm{C})$, high temperatures $(>30 \mathrm{C})$, the vapor pressure of the herbicide, dew present at application, high wind at application, low wind at application, high humidity, low humidity, and the particular formulation of the herbicide. The respondents were asked to select all of the factors that can contribute to the volatilization potential of an herbicide (Figure 5). Of the 427 commercial and 1,535 noncommercial applicators who answered the question, high temperature was the most commonly selected factor, chosen by over $70 \%$ of all respondents. Only $48 \%$ of commercial and $39 \%$ of noncommercial applicators selected vapor pressure of the herbicide as a factor contributing to volatility.
The results, presented in detail in Figure 5, indicate that both commercial and noncommercial applicators are familiar with some, but not all, of the factors that can contribute to volatility of herbicides, and highlight the need for better understanding of these points. Emphasizing the role of volatility in synthetic auxin herbicide movement will help applicators better appreciate the need to follow the label and use low-volatility synthetic auxin herbicides.

Another element that can contribute to off-target herbicide movement but can be hard to detect is a surface temperature inversion, which occurs when the air near the earth's surface is cooler than the air further away from the earth's surface (Enz et al. 2014). When cool air settles below warm air, a stable, stagnant air mass is produced. Many approved 2,4-D and dicamba herbicide labels indicate that applications should not be made during temperature inversions, because small herbicide particles may be suspended in the stable air mass instead of reaching target plants and can be moved to unintended targets (Anonymous 2006; Anonymous 2008; Anonymous 2010; Anonymous 2012; Anonymous 2016). In this survey, applicators were given nine choices for environmental signs of a temperature inversion, including very calm conditions $\left(<4.8 \mathrm{~km} \mathrm{hr}^{-1}\right.$ wind 


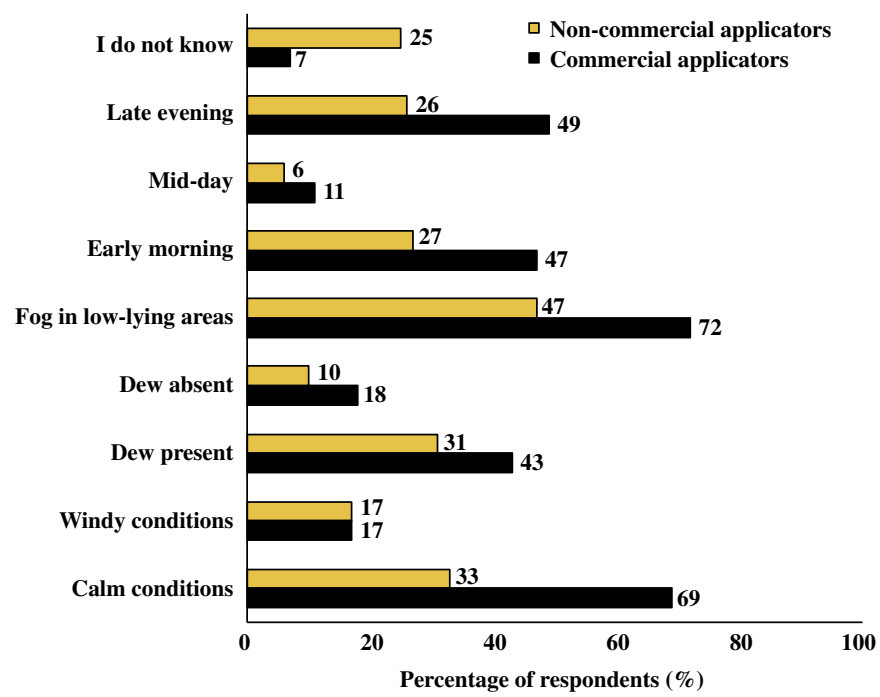

Figure 6. Factors that serve as indicators of a temperature inversion. Herbicide applicators were asked whether each of the listed factors (y-axis) were environmental "cues" of temperature inversions. For calm conditions, respondents were given a cutoff of wind speeds $<5 \mathrm{~km} \mathrm{~h}^{-1}$. Gold bars represent the percentage of noncommercial applicators $(n=1,878)$ who selected a given factor. Black bars represent the percentage of commercial applicators $(n=457)$ who indicated that a given factor could be a sign of a temperature inversion.

speed), windy conditions, dew present, dew absent, fog in low-lying areas, early morning, mid-day, late evening, or "I do not know". Respondents were asked to select all choices that are indicative of temperature inversions. Of the 457 commercial and 1,878 noncommercial applicators who responded, the most frequently selected (and also correct) option was fog in low-lying areas (Figure 6). Approximately $69 \%$ of commercial applicators selected very calm winds and $50 \%$ chose late evening, both of which can indicate a temperature inversion is occurring. With the exception of fog in low-lying areas, the noncommercial group of applicators did not select any of the other possible cues more than $50 \%$ of the time. Only $25 \%$ of noncommercial and $7 \%$ of commercial applicators selected "I do not know" with regard to cues of temperature inversions, less than $50 \%$ of total respondents indicated the correct cues of dew present, very calm conditions, late evening, or early morning hours. Data from this question indicate that further education on temperature inversions is needed for Missouri pesticide applicators.

The survey data reported herein provides information regarding current pesticide applicator knowledge and practices, and highlights areas that need more emphasis during applicator training. Answers from the survey indicate that further education is needed on some aspects of the synthetic auxin technologies, such as what herbicides can be used with each technology, what volatility is, what a temperature inversion is, and proper methods for inspecting and cleaning spray equipment. The research also suggests that current methods aimed to facilitate communication among specialty crop producers and applicators may not be successfully adopted, at least in Missouri. Weed scientists can utilize this information to enhance training of pesticide applicators in preparation for the synthetic auxin herbicide technologies.

\section{Acknowledgements}

The authors would like to thank the Missouri Department of Agriculture for supplying the list of currently licensed pesticide applicators, and those applicators who took time to complete and return the survey. They would also like to thank Meghan Biggs, Malynda O'Day, Austin Straatman, Wyatt Coffman, Blake Kasten, Drake Gleeson, and Shea Farrell for their assistance in mailing out surveys and data entry.

\section{Literature Cited}

Akesson NB, Yates WE (1964) Problems relating to application of agricultural chemicals and resulting drift residues. Annu Rev Entomol 9:285-318

Al-Khatib K, Parker R, Fuerst EP (1992) Alfalfa response to simulated herbicide spray drift. Weed Technol 6:956-960

Al-Khatib K, Parker R, Fuerst EP (1993) Wine grape response to simulated herbicide drift. Weed Technol 7:97-102

Al-Khatib K, Peterson D (1999) Soybean (Glycine max) response to simulated drift from selected sulfonylurea herbicides, dicamba, glyphosate, and glufosinate. Weed Technol 13:264-270

Anonymous (2006) Banvel $^{\mathrm{R}}$ herbicide product label. Arysta Lifesciences North America, LLC Publication No. AD091109. Research Triangle Park, NC: Arysta Lifesciences. 29 p

Anonymous (2008) 2,4-D Amine 4 herbicide product label. EPA Registration No. 1381-103. St. Paul, MN: Winfield Solutions, LLC. $21 \mathrm{p}$

Anonymous (2010) Clarity $^{\mathrm{R}}$ herbicide product label. BASF Corporation Publication No. NVA 2010-04-065-0154. Research Triangle Park, NC: BASF. $22 \mathrm{p}$

Anonymous (2012) Shredder ${ }^{\text {TM }}$ 2,4-D LV6 herbicide product label. EPA Registration No. 1381-250. St. Paul, MN: Winfield Solutions, LLC. $12 \mathrm{p}$

Anonymous (2016) Enlist Duo ${ }^{\mathrm{TM}}$ with Colex-D Technology herbicide product label. DowAgroSciences Publication No. H-59334. Indianapolis, IN: DowAgroScience. 7 p 
Creech CF, Henry RS, Fritz BK, Kruger GR (2015) Influence of herbicide active ingredient, nozzle type, orifice size, spray pressure, and carrier volume rate on spray droplet size characteristics. Weed Technol 29:298-310

Cundiff GT, Reynolds DB, Thomas W, Mueller T (2016) Evaluation of sequestration of dicamba in sprayer hoses. Weed Science Society of America Annual Meeting Abstracts 51:306

[EPA] Environmental Protection Agency (2016) Compliance Advisory: High Number of Complaints Related to Alleged Misuse of Dicamba Raises Concerns. https://www.epa.gov/sites/ production/files/2016-08/documents/fifra-dicambacompliance advisory.pdf. Accessed September 12, 2016

Enz JW, Hofman V, Thostenson A (2014) Air Temperature Inversions: Causes, Characteristics, and Potential Effects on Pesticide Spray Drift. North Dakota State University Extension Service. https://www.ag.ndsu.edu/pubs/plantsci/pests/ae1705.pdf. Accessed September 12, 2016

Everitt JD, Keeling JW (2009) Cotton growth and yield response to simulated 2,4-D and dicamba drift. Weed Technol 23:503-506

Godar AS, Stahlman PW (2015) Consultant's perspective on the evolution and management of glyphosate-resistant kochia (Kochia scoparia) in western Kansas. Weed Technol 29:318-328

Heap I (2016) The International Survey of Herbicide Resistant Weeds. www.weedscience.org. Accessed August 23, 2016

Inman MD, Jordan DL, York AC, Jennings KM, Monks DW, Everman WJ, Bollman SL, Fowler JT, Cole RM, Soteres JK (2016) Long-term management of Palmer amaranth (Amaranthus palmeri) in dicamba-tolerant cotton. Weed Sci 64:161-169

Legleiter TR, Bradley KW (2008) Glyphosate and multiple herbicide resistance in common waterhemp (Amaranthus rudis) populations from Missouri. Weed Technol 56:582-587

Maybank J, Yoshida K, Grover R (1978) Spray drift from agricultural pesticide applications. J Air Pollut Control Assoc 28:1009-1014

Maynard E, Overstreet B, Riddle J (2012). Watch Out for: Pesticide Drift and Organic Production. Lafayette, IN: Purdue Extension Pub. DW-1-W. https://www.extension.purdue.edu/ extmedia/ho/dw-1-w.pdf. Accessed October 24, 2016

Norsworthy JK, Bond J, Scott RC (2013) Weed management practices and needs in Arkansas and Mississippi rice. Weed Technol 27:623-630

Norsworthy JK, Griffith GM, Scott RC, Smith KL, Oliver LR (2008) Confirmation and control of glyphosate-resistant Palmer amaranth (Amaranthus palmeri) in Arkansas. Weed Technol 22:108-113

Pfleeger TG, Olszyk D, Burdick CA, King G, Kern J, Fletcher J (2006) Using a geographic information system to identify areas with potential for off-target pesticide exposure. Environ Toxicol Chem 25:2250-2259

Regnier EE, Harrison SK, Loux MM, Holloman C, Venkatesh R, Diekmann F, Taylor R, Ford RA, Stoltenberg DE, Hartzler RG, Davis AS, Schutte BJ, Cardina J, Mahoney KJ, Johnson WJ (2016) Certified crop advisors' perceptions of giant ragweed (Ambrosia trifida) distribution, herbicide resistance, and management in the Corn Belt. Weed Sci 64:361-377

Scott B, Saraswat D, Spradley P, Baker R (2011) Flag the Technology. Fayetteville, AR: University of Arkansas Division of Agriculture Research and Extension Pub. FSA2162. Revised 2014. https://www.uaex.edu/publications/pdf/FSA-2162.pdf. Accessed October 24, 2016
Shaw DR, Givens WA, Farno LA, Gerard PD, Jordan D, Johnson WG, Weller SC, Young BG, Wilson RG, Owen MDK (2009) Using a grower survey to assess the benefits and challenges of glyphosate-resistant cropping systems for weed management in U.S. corn, cotton, and soybean. Weed Technol 23:134-149

Sinzogan AAC, Van Huis A, Kossou DK, Jiggins J, Vodouhe S (2004) Farmers' knowledge and perception of cotton pests and pest control practices in Benin: results of a diagnostic study. NJAS Wageningen J of Life Sci 52:285-303

Solomon CB, Bradley KW (2014) Influence of application timings and sublethal rates of synthetic auxin herbicides on soybean. Weed Technol 28:454-464

Soltani N, Nurse RE, Sikkema PH (2016) Response of glyphosate-resistant soybean to dicamba spray tank contamination during vegetative and reproductive growth stages. Can J Plant Sci 96:160-164

Steckel L, Craig C, Thompson A (2010) Cleaning plant growth regulator (PGR) herbicides out of field sprayers. Knoxville, TN: The University of Tennessee Agricultural Extension Service Pub W071:3 p

[USDA-APHIS] US Department of Agriculture-Animal and Plant Health Inspection Service (2014) Determination of Nonregulated Status for Dow AgroSciences DAS-68416-4 Soybean. Washington, DC: US Department of Agriculture. https://www. aphis.usda.gov/brs/aphisdocs/11_23401p_det.pdf. Accessed September 12, 2016

[USDA-APHIS] US Department of Agriculture-Animal and Plant Health Inspection Service (2015a) Determination of Nonregulated Status for Dow AgroSciences DAS-8190-7 Cotton. Washington, DC: US Department of Agriculture. https://www. aphis.usda.gov/brs/aphisdocs/13_26201p_pdet.pdf. Accessed September 12, 2016

[USDA-APHIS] US Department of Agriculture-Animal and Plant Health Inspection Service. (2015b) Determination of Nonregulated Status for Monsanto Company MON 88701 cotton. Washington, DC: US Department of Agriculture. https://www. aphis.usda.gov/brs/aphisdocs/12_18501p_det.pdf. Accessed September 12, 2016

[USDA-APHIS] US Department of Agriculture-Animal and Plant Health Inspection Service. (2015c) Determination of Nonregulated Status for Monsanto Company MON 88708 soybean. Washington, DC: US Department of Agriculture. https://www.aphis.usda.gov/brs/aphisdocs/10_18801p_det.pdf. Accessed September 12, 2016

[USDA-NASS] US Department of Agriculture-National Agricultural Statistics Service (2012) Census of Agriculture, Ag Census Web Maps. Washington, DC: US Department of Agriculture. https://www.agcensus.usda.gov/Publications/2012/. Accessed July 22, 2016

VanGessel MJ, Johnson QR (2005) Evaluating drift control agents to reduce short distance movement and effect on herbicide performance. Weed Technol 19:78-85

Received September 15, 2016, and approved December 5, 2016.

Associate Editor for this paper: Lawrence E. Steckel, University of Tennessee. 